\title{
GENDER DIFFERENCES IN SIMULTANEOUS POLYDRUG USE AMONG UNDERGRADUATE STUDENTS OF ONE UNIVERSITY, KINGSTON - JAMAICA
}

\author{
Patrice Whitehorne-Smith ${ }^{1}$, Laura Simich ${ }^{2}$, Carol Strike ${ }^{3}$ Bruna Brands ${ }^{4}$, Norman Giesbrecht $^{5}$, Akwatu Khenti ${ }^{6}$
}

${ }^{1}$ Psychologist. Masters in Clinical Psychology. Formerly of the University of the West Indies. Currently Research Co-ordinator, Social Development Commission. Jamaica. E-mail: patrice.whitehorne@yahoo.com

2 Ph.D. Investigator. Health Systems Research and Consulting Unit. Centre for Addiction and Mental Health. University of Toronto. Toronto, Canada. E-mail: laura_simch@camh.net

${ }^{3}$ Ph.D. Investigator. Health Systems Research and Consulting Unit. Centre for Addiction and Mental Health. University of Toronto. Toronto, Canada. E-mail: carol_strike@camh.net

${ }^{4}$ Ph.D. Investigator, Office of Research and Surveillance. Drug Strategy and Controlled Substances Programme. Health Canada and Public Health and Regulatory Policies. Center for Addiction and Mental Health. University Toronto. Toronto, Canada. E-mail: bruna_brands@camh.net

${ }^{5}$ Ph.D. Researcher. Health Systems Research and Consulting Unit. Centre for Addiction and Mental Health. University of Toronto, Canada. E-mail: norman_giebsbrecht@camh.net

${ }^{6}$ MSc. Director International Health Office. Centre for Addiction and Mental Health. Toronto, Canada. E-mail: akwatu_khenti@ camh.net

ABSTRACT: This study sought to explore the simultaneous polydrug use pattern across genders of $1^{\text {st }}$ and $2^{\text {nd }}$ year undergraduate students in one university in Kingston, Jamaica. There were 295 study participants (58 males and 237 females) from the faculty of Medical Sciences at a local university. The study used a self administered questionnaire which addressed various aspects of drug use and simultaneous polydrug use. Unadjusted results revealed a significantly higher simultaneous polydrug use among males than females $40.9 \%$ and $14.3 \%$ respectively in the last 12 months $\left(\chi^{2}, p=0.009\right)$ and in the last 30 days $8.9 \%$ vs. $1.7 \%\left(\chi^{2}, p=0.014\right)$. These results suggest a prominence of simultaneous polydrug use behaviour among male undergraduate students in this population compared with females, although further research is required.

DESCRIPTORS: Students. Street drugs. Behaviour addictive. Substance-Related disorders. Risk factors.

\section{DIFERENCIAS DE GÉNERO EN EL POLICONSUMO SIMULTÁNEO DE DROGAS ENTRE ESTUDIANTES DE PREGRADO EN UNA UNIVERSIDAD, KINGSTON - JAMAICA}

RESUMEN: Este estudio tuvo como objetivo explorar el patrón comparativo de policonsumo simultáneo de drogas entre géneros, en estudiantes de $1^{\circ}$ y $2^{\circ}$ año de pregrado en una universidad en Kingston, Jamaica. Hubo 295 participantes en el estudio (58 hombres y 237 mujeres) de la Facultad de Ciencias Médicas de esta universidad local. El estudio utilizó un cuestionario auto-administrado en el que se abordaron diversos aspectos del consumo y poli-consumo simultáneo de drogas. Los resultados no-ajustados revelaron un significativo mayor nivel de policonsumo simultaneo en hombres que en mujeres $40,9 \%$ y $14,3 \%$ respectivamente en los últimos 12 meses $\left(\chi^{2}, p=0,009\right)$ y en los últimos 30 días $8,9 \%$ vs. $1,7 \%\left(\chi^{2}, p=0,014\right)$. Estos resultados sugieren un predominio en el comportamiento de policonsumo simultáneo de drogas entre hombres estudiantes de pregrado en esta población comparado con mujeres, aunque se refiere investigación adicional.

DESCRIPTORES: Estudiantes. Drogas ilícitas. Conducta adictiva. Transtornos relacionados com substancias. Factores de riesgo.

\section{DIFERENÇAS DE GÊNERO NO POLICONSUMO SIMULTÂNEO DE DROGAS ENTRE ESTUDANTES DE GRADUAÇÃO EM UMA UNIVERSIDADE, KINGSTON - JAMAICA}

\begin{abstract}
RESUMO: Este estudo procurou explorar o padrão de policonsumo simultâneo de drogas entre diferentes sexos de alunos do $1^{\circ}$ e $2^{\circ}$ ano de graduação em uma universidade em Kingston, Jamaica. Participaram do estudo 295 estudantes (58 homens e 237 mulheres) da Faculdade de Ciências Médicas em uma universidade local. O estudo utilizou um questionário auto-administrável que abordou diversos aspectos do uso de drogas e policonsumo simultâneo de drogas. Os resultados não ajustados revelaram que o uso entre os homens são significativamente maiores do que as mulheres $40,9 \%$ e 14,3\% respectivamente foram encontrados uso simultâneos de drogas nos últimos 12 meses $\left(\chi^{2}, p=0,009\right)$ e nos últimos 30 dias $8,9 \%$ vs. $1,7 \%\left(\chi^{2}, p=0,014\right)$. Estes resultados sugerem uma predominância no comportamento dos policonsumo de drogas entre os homens de graduação nesta população em relação às mulheres, embora a necessidade de mais pesquisas nessa área.
\end{abstract}

DESCRITORES: Estudantes. Efeitos de drogas. Comportamento aditivo. Transtornos relacionados ao uso de substâncias. Fatores de risco. 


\section{INTRODUCTION}

Many researchers the world over have been highlighting a narrowing gap between males and females in terms of their drug use patterns with females now reflecting equal or greater use of both licit and illicit drugs to their male counterparts. ${ }^{1-5}$

These findings are of growing concerns especially as other researchers have noted that drug use during adolescence has a tendency to continue and increase during young adulthood and university life. ${ }^{6-7}$ Drug consumption among college students far exceeds use of drugs by non-college peers, an Ontario University Study reports. The study disclosed that $94.5 \%$ of students reported drinking alcoholic beverage within the last year the study was conducted. This compares with a reported $82.9 \%$ of non-college peers. ${ }^{8}$ Also a study conducted at a University in Brazil revealed that even though males used more drugs than females, the gender comparison showed an increased consumption of drugs among women. ${ }^{9}$

Additionally, university life is a time of experimentation and self discovery for many young adults resulting in heightened tendencies to engage in risky behaviours such as polydrug use. The use of more than one drug is especially common among adolescents and young adults and identified two distinct types of polydrug use patterns. ${ }^{10}$ They are simultaneous polydrug use and concurrent polydrug use. Simultaneous polydrug use refers to the ingestion of more than one drug on a single occasion of drug use while concurrent polydrug use refers to ingestion of different drugs on separate occasions..$^{10-11}$ Though both patterns are harmful to the individual consuming these drugs, simultaneous polydrug can create more serious short term consequences as the ingestion of more than one drug in the same sitting can create a combination or interaction of the effect of both drugs. This may result in greater intoxication, increased risk of injury and a heightened risk of lethality than if drugs were taken separately. ${ }^{10}$

A survey of second year students conducted in ten United Kingdom universities revealed that $20 \%$ of students were regular users of the drug. That is, they used the drug weekly or more often. Overall, $34 \%$ of the participants were reported to be simultaneous polydrug users. ${ }^{12}$

In other study ${ }^{11}$ it was found that the prevalence for polydrug use involving alcohol and prescription drugs was $12.1 \%$ (including 6.9\% simultaneous polydrug users). The majority of polydrug consumption among respondents involved alcohol and prescription drugs with the exception of sleeping medication. The study found that simultaneous polydrug use was more prevalent among undergraduate students who were male, and whose initiation of alcohol use was at an early age. Simultaneous polydrug consumption was also found to be associated with more alcoholrelated and other drug use-related problems than concurrent polydrug consumption.

Researchers at the University of Michigan discovered that young adults were most at risk for concurrent or simultaneous abuse of both alcohol and prescription drugs. They found that among a mid-western university student population $7 \%$ of the respondents had within the last year ingested prescription drug non-medically, at the same time with alcohol. ${ }^{13}$ Similarly among an Australian tertiary student population one quarter of the students who participated in the study used alcohol and tobacco on the same occasion in the last six months of the study. ${ }^{14}$ In that same period, one in every twenty student used cannabis and amphetamines or ecstasy; one percent used opiates and cannabis on the same occasion.

Studying students from the medical/health science fields was of particular interest because research has shown that many individuals from the medical/health sciences career are drug users/ abusers. From a sample of 133 medical students in United States nearly all used alcohol, 57\% used cannabis, $20 \%$ cocaine and $40 \%$ used opioids. ${ }^{15}$ Many medical students began using drugs prior to medical school. The drug they most frequently used was alcohol.

Furthermore the use of licit and/or illicit psychoactive drugs by individuals of medical/health science profession can be detrimental for others, as their responsibility and judgment as service providers may be compromised and result in harm to others.Given the growing awareness of researchers of the prominence of polydrug consumption among university students and the physical, social and psychological implications involved this area of study has become of outmost importance for the gathering of information especially in the regions of Latin America and the Caribbean where such studies are limited.

Consequently the current study sought to explore gender differences in simultaneous polydrug use patterns of first and second year medical/ health science students at a university in Jamaica. The research hypothesis was that males and fe- 
males will differ in the patterns of simultaneous polydrug use, with males using alcohol, tobacco and cannabis whereas females will use alcohol, tobacco and prescription drugs.

\section{METHOD}

This study was part of a multicentric project involving seven universities from the countries of Brazil, Colombia, Chile, El Salvador, Guatemala, Jamaica and Nicaragua. The findings in this article includes only one university in Kingston, Jamaica.

The design used in this research was crosssectional, with a survey method of data collection. The study was based on a self-reported questionnaire developed by the researchers. The questionnaire consists of four sections with 58 closed ended questions which allowed respondents to provide additional information where necessary.

The target population was undergraduate university student who were in the first and second years of Medical/Health Sciences programs in one university in Kingston, Jamaica. Researchers randomly selected compulsory courses for $1^{\text {st }}$ and $2^{\text {nd }}$ year from each program in the Medical/ Health Sciences. The data was collected in lecture settings across compulsory classes in the Medical Sciences faculty. Researchers were present for the first 5-10 minutes of classes to provide instructions and answer research related questions. Questionnaires and informed consent forms were then distributed to students by research assistants and a 15 minute collection time was allowed before collecting questionnaires.

The statistical analysis was essentially descriptive, including frequency distributions. Inferential comparisons were performed through chi-square methods. The data analysis was performed using the statistical software package SPSS, version 15.0 for Windows.

Ethical approval was granted by the Centre for Addition and Mental Health Ethical Committee in Canada and the Ethical Committee of the University in Kingston, Jamaica..

\section{RESULTS}

The sample was compound by 295 participants, 58 males and 237 females. Table 1, summarizes socio-demographic information. Most of the participants were females $80.3 \%$, nurses $37.6 \%$ and in the first year of their university programs $70.5 \%$.
Table 1 - Description of study participants, University in Kingston, Jamaica, 2009 (n=295)

\begin{tabular}{lrr}
\hline \multicolumn{1}{c}{ Variables } & N & $\%$ \\
\hline Sex & 58 & 19.7 \\
Male & 237 & 80.3 \\
Female & & \\
University Major & 42 & 14.2 \\
Medicine & 71 & 24.2 \\
Basic Medicine & 111 & 37.6 \\
Nursing & 8 & 2.7 \\
Pharmacy & 62 & 21.0 \\
Psychology & 1 & 0.3 \\
No Response & & \\
Current year in University & 208 & 70.5 \\
$1^{\text {st }}$ year & 86 & 29.2 \\
$2^{\text {nd }}$ year & 1 & 0.3 \\
No response & & \\
\hline
\end{tabular}

Study findings revealed that male participants reported higher psychoactive drugs use in their lifetime $46.6 \%$ compared with females $31.2 \%$. Chi-square test revealed a significant difference for this category $(p=0.020)$. The reported rates for the 12 months period were $39.7 \%$ for males and $26.6 \%$ for females, difference that resulted significant at $90 \%$ significance level $\left(\chi^{2}, \mathrm{p}=0.061\right)$.

Regarding simultaneous polydrug use, $40.9 \%$ of males and $14.3 \%$ of females reported this pattern of consumption for the last 12 months $\left(\chi^{2}, p=0.009\right)$, and for 30 days the number were $8.6 \%$ for males and $1.7 \%$ for females $\left(\chi^{2}, p=0.014\right)$, which was considered significant at the $95 \%$ level for both categories.

Table 2 - Combination of drugs used in the last 12 months by Gender, University in KingstonJamaica, 2009 (n=295)

\begin{tabular}{lcccc}
\hline \multirow{2}{*}{$\begin{array}{l}\text { Combination of drugs used last } \\
\mathbf{1 2} \text { months }\end{array}$} & \multicolumn{2}{c}{ Male } & \multicolumn{2}{c}{ Female } \\
\cline { 2 - 6 } & $\mathbf{N}$ & $\mathbf{\%}$ & $\mathbf{N}$ & $\%$ \\
\hline Alcohol + cannabis & 4 & $6.9 \%$ & 6 & $2.5 \%$ \\
Alcohol + cocaine & - & - & - & - \\
Alcohol + Prescription drug & 1 & $1.7 \%$ & 1 & $0.4 \%$ \\
Alcohol + tobacco + cannabis & 2 & $3.4 \%$ & 3 & $1.3 \%$ \\
Alcohol + cocaine + tobacco & - & - & - & - \\
Alcohol + cocaine + cannabis + & - & - & - & - \\
tobacco & - & - & & \\
Cannabis + cocaine & - & - & - & - \\
Cannabis + prescription drugs & - & - & - & - \\
Tobacco + cannabis & - & - & 3 & $1.3 \%$ \\
Tobacco + prescription drug & - & - & - & - \\
Other combination & - & - & - & - \\
\hline
\end{tabular}


Table 3 - Combination of drugs used in the last 30 days by gender, university in Kingston-Jamaica, $2009(n=295)$

\begin{tabular}{lcccc}
\hline Combination of drugs used & \multicolumn{2}{c}{ Male } & \multicolumn{2}{c}{ Female } \\
\cline { 2 - 5 } last $\mathbf{3 0}$ days & $\mathbf{N}$ & $\%$ & $\mathbf{N}$ & $\%$ \\
\hline Alcohol + cannabis & 2 & $3.4 \%$ & 2 & $0.8 \%$ \\
Alcohol + cocaine & - & $0 \%$ & - & - \\
Alcohol + prescription drug & 1 & $1.7 \%$ & - & - \\
Alcohol + tobacco + cannabis & 2 & $3.4 \%$ & 2 & $0.8 \%$ \\
Alcohol + cocaine + tobacco & - & - & - & - \\
Alcohol + cocaine + cannabis + & - & - & - & - \\
tobacco & - & - & - & - \\
Cannabis + cocaine & - & - & - & - \\
Cannabis + prescription drugs & - & - & 1 & $0.4 \%$ \\
Tobacco + cannabis & - & - & - & - \\
Tobacco + prescription drug & - & - & - \\
Other combination & - & - & - & - \\
\hline
\end{tabular}

Table 2 and 3, show the frequency in the reported use by combination of drugs in 12 month and 30 days respectively. The combination of alcohol and cannabis was the most commonly used, followed by alcohol, tobacco and cannabis. There were not differences in consumption of these combinations by gender.

\section{DISCUSSION}

The findings of this study reveal that the primary research hypothesis was not supported, as there were no significant differences between males and females in terms of combinations used for simultaneous polydrug consumption. However, our unadjusted analysis indicated a significant difference in overall polydrug use rates between male and female students, for both the 12 months and the 30 days categories.

These results are despite international findings of a closing in gender gap in overall drug use patterns. ${ }^{1-5}$ Gender differences were also significant for rates of general drug use.

As noted by certain authors, ${ }^{17}$ gender is a social construction of roles perpetuated by the agents of socialization (family, school, church, etc.), and factors significantly in the drug consumption pattern among men and women. Consequently, from societal standpoint, drug use behaviours may be seen as more acceptable among men than women. Also, the ability to consume risky drugs and withstand their effects is often seen as a positive sign of masculinity, ${ }^{18}$ whereas there are many social stigmas associated with female drug use.
That may also increase the degree of under report among our female participants. Additionally the use of alcohol and other drugs can attract different meanings for men and women in college life for example, Murphy et al. ${ }^{18}$ observed in their study that drinking among college males served to facilitate social interaction with their peers and served as a peer norm whereas this type of behaviour was not necessary for female social interactions and did not attract the same meaning.

\section{CONCLUSION}

This study explored the presence of simultaneous polydrug use among undergraduate university students in one university in Jamaica. Though, the reports of this form of drug use were not very prominent among the population studied, composed by Medical/Health Science students, gender differences in patterns of use were still identifiable and suggested that societal influences may play a role in the decision to engage in simultaneous polydrug use among males and females.

\section{Limitations}

The study was not representative of the general university population or the young population in the country. Additionally, and based on the natural distribution of males within the Medical/ Health Sciences population, there was an under representation of male students in relation to females, which may have prevented us to observe a true reflection of the simultaneous polydrug use among undergraduate students.

\section{Recommendations}

As this study was primarily designed to be exploratory in nature, it is recommended that future research seek to address the limitations of this study by carrying out broad based research across all faculties and seek to get equal numbers of male and female participants. This area of study is a very important one as it may have grave implications for the development of the region, thus serious research directed towards different aspects of simultaneous polydrug consumption is needed to create and facilitate effective prevention and intervention programmes across this region.

\section{Acknowledgments}

To the Government of Canada/DFAIT, Organization of American States (OAS), Inter- 
American Drug Control Commission (CICAD), Centre for Addiction and Mental Health (CAMH -Toronto/Canada) for supporting and endorsing this project as well as the other universities and students who participated in the sample and advisors and collaborators. Special thanks to Dr. Gustavo Mery, CAMH Reviewer, for his collaboration in the final revision and editorial aspects of all papers and reports of group III.

\section{REFERENCES}

1. National Council on Drug Abuse. National School Survey. Jamaica: National Council on Drug Abuse; 2006.

2. Schnike S, Di Noia J, Schwinn T, Cole K. Drug abuse risk and protective factors among black, urban adolescent girls: a group randomized trial of computer-delivered, mother-daughter intervention. Psychol Addict Behav. 2006 Dec; 20(4):496-500.

3. Substance Abuse and Mental Health Services Administration (SAMHSA). National household survey on drug abuse 1997[online]. SAMHSA; 1997 [access 2008 Jun]. Available at: http://www.oas.samhsa. gov/nhsda/1997Main/nhsda1997mfWeb.htm

4. Adlaf EM, Chestnut CA. Cayman Islands student drug use survey: prevalence report. Cayman Islands (KY): National Drug Council and Centre for Addiction and Mental Health; 2001.

5. Ministry of Planning, Implementation and Public Affairs in association with Organization of International States. National drug use prevalence survey: school and workplace Antigua and Barbuda. Antigua (AG): Organization of International States; 2001.

6. Douglas KG. Patterns of substance use and abuse among post primary students. Planning Institute of Jamaica: policy development unit. Kingston (JM): Pear Tree Press; 2000.

7. Krohn M, Lizotte AJ, Perez CM. The interrelationship between substance use and precocious transitions to adult statuses. J Health Social Behavior. 1997 Mar; 38(1):87-103.

8. Perkins HW. Surveying the damage: a review of research on consequences of alcohol misuse in college populations. J Stud Alcohol Suppl. 2002 Mar; (14):91-100.
9. Wagner GA, Stempliuk A, Zilberman ML, Barroso LP, Andrade AG. Alcohol and drug use among university students: gender differences. Rev Bras Psiquiatr 2007 Jun; 29(2):123-9.

10. Earleywine M, Newcomb MD. Concurrent versus simultaneous polydrug use: prevalence, correlates, discriminate validity, and prospective effects on health outcomes. Exp Clin Psychopharmacol. 1997 Nov; 5(4):353-64.

11. McCabe SE, Cranford JA, Morales M, Young A. Simultaneous and concurrent polydrug use of alcohol and prescription drugs: prevalence, correlates, and consequences. J Stud Alcohol. 2006 Jul; 67(4):529-37.

12. Webb E, Ashton CH, Kelly P, Kamali F. Alcohol and drug use in UK university student. Lancet. 1996 Oct 5; 348(9032):922-5.

13. Ashton E. Alcohol abuse makes prescription drug abuse more likely [online]. National Institute of drugs abuse; 2007 [acess 2008 Jul]. Available at: http://www.drugabuse.gov/NIDA_notes/ NNvol21N5/alcohol.html

14. O'Reily BO, Jessen J. Cannabis use among Australian tertiary students. South Pacific J Psychol. 2005; 6(1):18-29.

15. Maddux J, Hoppe S. Costello R. Psychoactive substance use among medical students. Am J Psychiatry. 1986 Feb; 143(2):187-91.

16. Creative Research Systems. Sample size calculator [online]. 2007 [acessed 2008 Jun]. Available at: www. surveysystems.com/sscale.htm

17. Panamerican Health Organization. Estudio multicentrico sobre consume de alcohol, cultura y genero 2006. Washington (US): PAHO; 2006.

18. Gore KA, Harris RJ, Firestone JM. Differences in male and female alcohol consumption [online]. Paper presented at the annual meeting of the American Sociological Association, Hilton San Francisco \& Renaissance Parc 55 Hotel, San Francisco, 2005 [accessed 2008 Jul]. Available at: http://www. allacademic.com/meta/p108984_index.html

19. Murphy JG, McDevitt-Murphy ME, Barnett NP. Drink and be merry? Gender, life satisfaction, and alcohol consumption among college students. Psychol Addict Behav. 2005 Jun; 19(2):184-91. 